\title{
Variable microstructural response of baddeleyite to shock metamorphism in young basaltic shergottite NWA 5298 and improved U-Pb dating of Solar System events
}

James R. Darlinga*, Desmond E. Moser ${ }^{\mathrm{b}}$, Ivan R. Barker ${ }^{\mathrm{b}}$, Kim T. Taitc, Kevin R. Chamberlain ${ }^{\mathrm{d}}$, Axel K. Schmitte,f and Brendt C. Hydec

${ }^{a}$ School of Earth and Environmental Sciences, University of Portsmouth, Portsmouth PO1 3QL, UK.

${ }^{\mathrm{b}}$ Department of Earth Sciences, University of Western Ontario, London, Ontario N6A 5B7, Canada. c Department of Natural History, Mineralogy, Royal Ontario Museum, Toronto, Ontario M5S 2C6, Canada.

d Department of Geology and Geophysics, University of Wyoming, 3006, Laramie, Wyoming 82071, USA

e Department of Earth and Space Sciences, UCLA, Los Angeles, California 90095, USA

${ }_{\mathrm{f}}^{\mathrm{f}}$ Institut für Geowissenschaften, Universität Heidelberg, 69120 Heidelberg, Germany

* Corresponding author: james.darling@port.ac.uk

\begin{abstract}
The accurate dating of igneous and impact events is vital for the understanding of Solar System evolution, but has been hampered by limited knowledge of how shock metamorphism affects mineral and whole-rock isotopic systems used for geochronology. Baddeleyite (monoclinic $\mathrm{ZrO}_{2}$ ) is a refractory mineral chronometer of great potential to date these processes due to its widespread occurrence in achondrites and robust $\mathrm{U}-\mathrm{Pb}$ isotopic systematics, but there is little understanding of shock-effects on this phase. Here we present new nano-structural measurements of baddeleyite grains in a thin-section of the highly-shocked basaltic shergottite Northwest Africa (NWA) 5298, using high-resolution electron backscattered diffraction (EBSD) and scanning transmission electron microscopy (STEM) techniques, to investigate shock-effects and their linkage with U-Pb isotopic disturbance that has previously been documented by in-situ $\mathrm{U}-\mathrm{Pb}$ isotopic analyses.
\end{abstract}

The shock-altered state of originally igneous baddeleyite grains is highly variable across the thinsection and often within single grains. Analyzed grains range from those that preserve primary (magmatic) twinning and trace-element zonation (baddeleyite shock Group 1), to quasi-amorphous $\mathrm{ZrO}_{2}$ (Group 2) and to recrystallized micro-granular domains of baddeleyite (Group 3). These 
groups correlate closely with measured $\mathrm{U}-\mathrm{Pb}$ isotope compositions. Primary igneous features in Group 1 baddeleyites $(n=5)$ are retained in high shock impedance grain environments, and an average of these grains yields a revised late-Amazonian magmatic crystallization age of $175 \pm 30 \mathrm{Ma}$ for this shergottite. The youngest U-Pb dates occur from Group 3 recrystallized nano- to microgranular baddeleyite grains, indicating that it is post-shock heating and new mineral growth that drives much of the isotopic disturbance, rather than just shock deformation and phase transitions.

Our data demonstrate that a systematic multi-stage microstructural evolution in baddeleyite results from a single cycle of shock-loading, heating and cooling during transit to space, and that this leads to variable disturbance of the $\mathrm{U}-\mathrm{Pb}$ isotope system. Furthermore, by linking in-situ $\mathrm{U}-\mathrm{Pb}$ isotopic measurements with detailed micro- to nano-structural analyses, it is possible to resolve the timing of both endogenic crustal processes and impact events in highly-shocked planetary materials using baddeleyite. This opens up new opportunities to refine the timing of major events across the Solar System.

Keywords: Mars; shergottite; geochronology; baddeleyite; EBSD; uranium-lead 
1

\section{Introduction}

2

Achondrites provide unique insights into planetary evolution in the inner Solar System. To fully understand the record that these precious igneous meteorites provide, it is critical to distinguish the effects of extreme compression and heating that occur during impact events from the original characteristics of the sample. Such "shock metamorphism" affects all meteorites during their ejection from planetary surfaces, and can produce transformation, deformation and pathways for chemical exchange amongst their constituent mineral phases. As a result, accurate radiometric dating of events recorded by meteorites from the Moon, Mars and the asteroid belt is often highly challenging: a reflection of our inability to resolve, by geochemical methods alone, the severity of mineral age resetting by impact events.

The implications for our understanding of planetary evolution can be huge. In the case of shergottites, basaltic meteorites from Mars (e.g. Marti et al., 1995; Meyer, 2012), debate over the effects of shock metamorphism on different isotopic systems used for dating has led to interpreted crystallization ages of individual meteorites that vary by as much as 4 billion years (Gyr). The shergottites yield Rb-Sr, U-Pb, Sm$\mathrm{Nd}$ and Lu-Hf isotope mineral and whole-rock isochrons with relatively young ages of between ca. 150 and $600 \mathrm{Ma}$ (e.g. Shih et al., 1982; Chen and Wasserburg, 1986; Jagoutz and Wanke, 1986; Jones, 1986; Nyquist et al., 2001; Borg et al., 2002; 2003; 2009). However, Pb-Pb isotope data from a range of shergottites have been interpreted to represent mineral isochrones that yield ancient ages of 4.1-4.5 Ga (Bouvier et al., 2005, 2008, 2009). This has led to debate as to whether the younger isochron ages reflect the timing of Martian magmatism or disturbance by metamorphic events on Mars, including shock metamorphism before and during meteorite ejection. The interpretation of isotopic results based on bulk mineral separate techniques is especially challenging given the susceptibility of these data to the presence of minor phases (e.g. phosphate inclusions), terrestrial or Martian contamination or preferential leaching during acid washing.

The dating of individual uranium-bearing accessory phases using in-situ methods is much less susceptible to such effects, and has great potential to push forward understanding of Martian chronology. Baddeleyite, monoclinic $\mathrm{ZrO}_{2}$, is a common accessory mineral in mafic igneous rocks and has been found 
in many shergottites (e.g., Niihara, 2011; Jiang and Hsu, 2012; Moser et al., 2013; Zhou et al., 2013), Lunar meteorites (e.g. Wang et al., 2012), other achondrites and chondrites (e.g. Krot et al., 1993). Similarly to zircon (tetragonal $\mathrm{ZrSiO}_{4}$ ), the benchmark chronometer of geological time on Earth, baddeleyite takes up significant quantities of $\mathrm{U}$ (up to thousands of ppm), typically excludes initial common- $\mathrm{Pb}$ (Heaman, 2009), and is very resistant to Pb-loss during crustal and weathering processes. Recent studies have shown that baddeleyites record young ages in the Roberts Massif 04261 (ca. 200 Ma; Niihara, 2011), Grove Mountains 020090 (192 \pm 10 Ma; Jiang and Hsu, 2012), Northwest Africa (NWA) 5298 (187 \pm 33 Ma, Moser et al., 2013), and Zagami (187 \pm 6.9 Ma; Zhou et al., 2013) shergottites, although questions persist as to whether the young dates reflect crystallization of the magmatic protolith or disturbance by multiple shock metamorphic events by processes including reversion from unquenchable high-pressure polymorphs back to the monoclinic baddeleyite structure (El Goresy et al., 2013).

Laboratory experiments predict that shock-loading up to $57 \mathrm{GPa}$ and attendant heating do not cause significant Pb-loss from baddeleyite (Niihara et al., 2012). However, contrary results are presented by Moser et al. (2013), who demonstrate that baddeleyite grains in the highly-shocked meteorite NWA 5298 have been structurally altered by shock metamorphism, with degraded crystallinity in some grains, and that the shock metamorphism caused by the launch event resulted in minor to approximately $80 \%$ loss of radiogenic $\mathrm{Pb}$ from baddeleyite. Nowhere in that study was there any report of baddeleyite melting, as mistakenly claimed by Werner et al. (2014). Such mis-interpretation of documented observations has led to the unsupported inferences that the shergottites, the largest class of Martian meteorites, are a) older than $4 \mathrm{Ga}$ in age, and b) from a single crater source in the southern highlands. There is thus a clear need to thoroughly establish the micro- to nano-structural states of shergottite baddeleyite grains and their relation to $\mathrm{U}-\mathrm{Pb}$ systematics, to establish a framework for more substantive interpretation of isotopic ages.

Here we address this issue by applying powerful techniques for in-situ crystallographic and nano-structural measurements, including electron backscatter diffraction (EBSD) and scanning transmission electron microscopy (STEM), to shock metamorphosed baddeleyite. We present new backscattered electron (BSE) imaging, cathodoluminescence (CL) imaging, EBSD data and STEM analyses for 42 grains in a single 
thin-section of the highly-shocked basaltic shergottite NWA 5298. These include 15 grains with previously reported $\mathrm{U}-\mathrm{Pb}$ isotope ratios (Moser et al., 2013). The principal aim is to better document the range of micro- to nano-structures caused by shock metamorphism on baddeleyite and to test the apparent correlation with $\mathrm{U}-\mathrm{Pb}$ age disturbance, with the hope of better informing future geochronology of planetary materials.

\section{Basaltic shergottite northwest Africa 5298}

Meteorite NWA 5298 is an unbrecciated, evolved basaltic shergottite with a primary phaneritic igneous texture (Irving and Kuehner, 2008). Apart from its relatively oxidized state, being close to the QFM buffer, it is chemically similar to other basaltic shergottites including Shergotty, Zagami and Los Angeles (Hui et al., 2011). As shown in Figure 1, the meteorite is predominantly comprised of zoned clinopyroxene $(65.1 \%)$ and shocked plagioclase $(30.0 \%)$, along with phosphates (merrillite and apatite; $2.1 \%$ ), Fe-Ti oxides (ilmenite and titanomagnetite; 2.0\%), silica (0.5\%) and mesostasis (aphanitic interstitial late-stage melt at the margins of phosphate and plagioclase grains; $0.5 \%$ ). Clinopyroxene crystals occur as prismatic grains up to $4 \mathrm{~mm}$ in length, and are irregularly zoned from pigeonite to augite compositions (Hui et al., 2011). The pyroxenes also contain domains with symplectites that are similar to some of the other basaltic shergottites: e.g. Shergotty, Zagami and Los Angeles (Aramovich et al., 2002; Warren et al., 2004). These symplectites consist of Ca-pyroxene, silica and fayalitic olivine, and are interpreted to have been formed via breakdown of ferrosilite-rich pyroxene (pyroxferroite breakdown material: PBM) at low pressure during cooling (Aramovich et al., 2002).

NWA 5298 is a highly shocked meteorite, and shock metamorphic features are pervasive throughout the studied sample. These include: (1) dark pockets of quenched, glassy impact melt up to 3 mm in diameter (Figure 1A;), which contain fragments of shocked and unmelted clinopyroxene with resorbed margins, and REE patterns that are parallel to that of phosphates in NWA 5298 (Hui et al., 2011), distinguishing them chemically from mesostasis; (2) highly fractured clinopyroxene grains exhibiting sub-parallel sets of irregularly-spaced fractures; (3) and pervasive transformation of plagioclase to an isotropic, glassy form (maskelynite). 
The maskelynite grains typically have central domains of isotropic glass with smooth textures in reflected light, and margins or entire grains with spherulitic textures and melt veins within surrounding clinopyroxene, suggesting that melting of the plagioclase was widespread (E.g. Fig 2A, B). Shock transformation of plagioclase in NWA 5298 (An40-55; Hui et al., 2011) to maskelynite suggests a shock pressure of at least $29 \mathrm{GPa}$ (Stöffler et al. 1986). Furthermore, the maskelynite is commonly vesicular, with vesicles up to hundreds of microns in diameter, similar to observations from other highly shocked shergottites including NWA 4797 (Walton et al., 2009), NWA 6342 (Irving et al., 2011) and Dhofar 378 (Ikeda et al., 2006). Given that vesiculation of silicate melts is inhibited at high pressures (Chen and El Goresy, 2000), this indicates that plagioclase melting took place at relatively low pressures during or immediately following decompression. This relative timing is supported by the presence of radiating fractures within pyroxene grains that surround maskelynite, as expected from volume increase of the maskelynite. Pyroxene grains in contact with maskelynite are locally transformed into micro-scale polycrystalline aggregates. Furthermore, parallel discontinuous lamellae of low-Ca pyroxene extend tens of $\mu \mathrm{m}$ from pyroxene grain margins into the maskelynite (Figure 2A), similar to textures observed in lherzolitic shergottite GRV 99027 (Wang and Chen, 2006). In combination, these observations indicate that NWA 5298 experienced shock metamorphic pressures of at least $30 \mathrm{GPa}$ during ejection from Mars.

Geochronological data for NWA 5298 is provided by Moser et al., (2013), who undertook secondary ion mass spectrometry (SIMS) U-Pb isotope analysis of baddeleyite grains in a thin-section of the meteorite. The fifteen analyzed grains have relatively low $\mathrm{U}$ abundances (about $50 \mu \mathrm{g} / \mathrm{g}$ to $300 \mu \mathrm{g} / \mathrm{g}$ ) compared to the Phalaborwa reference standard (51-2124 $\mu \mathrm{g} / \mathrm{g}$; Heaman, 2009), and proportions of radiogenic $\mathrm{Pb}$ that range widely from $97 \%$ to $19 \%$. The common- $\mathrm{Pb}$ corrected $\mathrm{U}-\mathrm{Pb}$ data form an array parallel to the Tera-

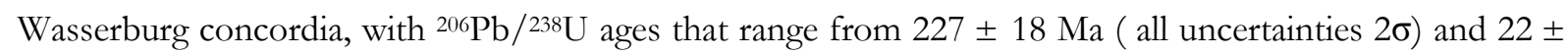
$2 \mathrm{Ma}$, indicative of varying degrees of relatively recent $\mathrm{Pb}$ loss (Moser et al., 2013). The data were also evaluated independently of the common- $\mathrm{Pb}$ correction, using a ${ }^{238} \mathrm{U}-206 \mathrm{~Pb}$ isochron diagram. The uncorrected data lie between reference isochrons of ca. $200 \mathrm{Ma}$ and $20 \mathrm{Ma}$, with ${ }^{206} \mathrm{~Pb} /{ }^{204} \mathrm{~Pb}$ ratios varying from highly radiogenic (highest $=554 \pm 166$ ) to unradiogenic (lowest $=16.0 \pm 1.6$ ). This demonstrates that the common- $\mathrm{Pb}$ correction applied was robust, and that the spread of measured $\mathrm{U}-\mathrm{Pb}$ ages relates to variable degrees of loss of radiogenic Pb. Moser et al., (2013) conclude that the measured baddeleyite 
grains pre-date the launch event because they are shocked, are cogenetic with host igneous minerals, and preserve primary igneous growth zoning. Moser et al., (2013) propose a crystallization age of $187 \pm 33 \mathrm{Ma}$ for NWA 5298, based upon a mean of the oldest measured grains, which also have the highest proportion of radiogenic $\mathrm{Pb}$.

\section{Methodology}

Micro- to nano-structural analyses were performed on a single polished thin-section of NWA 5298 (Fig. 1). The specimen is accession number M53387 from the Royal Ontario Museum's collection.

3.1 Field Emission Gun Scanning Electron Microscope (FEG-SEM) imaging and Energy Dispersive X-Ray (EDS) analysis

Baddeleyite grains in the thin-section were first located by X-ray mapping with an electron microprobe system at the University of Wyoming, using methods described by Chamberlain et al. (2010). Electron nanobeam analyses were performed at the Zircon and Accessory Phase Laboratory (ZAPLab), University of Western Ontario, using a Hitachi SU6600 FEG-SEM. The sample was vibratory polished (Buehler VibroMet 2) using a $0.05 \mu \mathrm{m}$ alumina suspension $(\mathrm{pH}=7)$ and carbon coated. Secondary electron (SE), backscatter electron (BSE) and colour cathodoluminescence (CL; Gatan ChromaCL detector) imaging was undertaken according to protocols described in detail elsewhere (Moser et al., 2011).

Following the first round of imaging, the thin-section was cut and a portion mounted for Secondary Ion Mass Spectrometry (SIMS). Additional EDS analyses were performed on the remaining sample, using an Oxford Instruments X-Max $80 \mathrm{~mm}^{2}$ silicon drift detector with INCA Energy software at the ZAPLab. Automated location of baddeleyite grains utilized the 'Feature' module of INCA Energy, combining BSE intensity and EDS spectrum to identify $\mathrm{ZrO}_{2}$ grains.

\subsection{Electron Backscatter Diffraction (EBSD)}

EBSD analyses were performed at the ZAPLab, using a Hitachi SU6600 FEG-SEM equipped with an Oxford Instruments Nordlys EBSD detector. The sample was tilted to $70^{\circ}$ and a $20 \mathrm{kV}, 8.0 \mathrm{nA}$ electron 
beam was used to generate EBSD "maps", consisting of an orthogonal grid of electron backscatter diffraction patterns (EBSPs) acquired at step-sizes ranging from 50 to $150 \mathrm{~nm}$. Run conditions for EBSD analysis are summarized in Table 1 . The only post-analysis noise reduction processing performed was to replace 'wild-spikes' ( interpreted as isolated, erroneously-indexed pixels) with a zero solution.

\subsection{Scanning Transmission Electron Microscopy (STEM)}

Fabrication of an electron transparent foil from shocked baddeleyite and subsequent Scanning Transmission Electron Microscopy (STEM) analyses were carried out at the Canadian Centre for Electron Microscopy, McMaster University. The foil was produced via focused ion beam (FIB) milling, using a Zeiss NVision 40 field emission gun cross-beam system with a $\mathrm{Ga}^{+}$ion beam. A $30 \mathrm{kV}$ ion beam was used for milling and $<5 \mathrm{kV}$ for final polishing to remove and prevent ion-impact damage. During FIB milling 'support beams' of thicker material in the foil section were maintained in order to provide rigidity in suspected weak (microfracture) areas and avoid any distortion of the intervening thin regions. STEM imaging was performed in high angular aperture dark field (HAADF) mode using a FEI Titan 80-300HB at beam conditions of $300 \mathrm{kV}$ and $\sim 50 \mathrm{pA}$. Camera distance was adjusted to image both variations in average atomic number of phases and crystallographic orientation.

\section{Results}

\subsection{Distribution of baddeleyite in NWA 5298 thin section}

Over $220 \mathrm{ZrO}_{2}$ grains with surface exposure areas greater than $17 \mu \mathrm{m}^{2}$ were located in a single thinsection. These include 29 grains with areas greater than $125 \mu \mathrm{m}^{2}$. The $x-y-z$ stage coordinates $(\mathrm{mm})$ relative to reference points and dimensional data for each identified $\mathrm{ZrO}_{2}$ grain were recorded and assigned unique 'Feature' numbers, allowing for unequivocal relocation of each identified grain during subsequent analyses. Grain lengths ranged from $6 \mu \mathrm{m}$ to $43 \mu \mathrm{m}$, with variable crystal habits from subequant to bladed with aspect ratios as high as 10:1 (average $=2$ ). The petrographic setting of these grains is highly variable (A.1), and examples of the petrographic context of analysed grains are presented in Figure 2. From most to least common these are: (a) clinopyroxene-maskelynite grain boundaries, (b) 
enclosed within maskelynite, (c) enclosed within clinopyroxene and pyroxferroite breakdown assemblages, (d) Fe-Ti-oxide-maskelynite or Fe-Ti-oxide-clinopyroxene grain boundaries, (e) partially or fully enclosed within mesostasis; (f) partially or fully enclosed within impact melt pockets, and (g) a component of polyphase inclusions within phosphates. For the vast majority of grains (settings a-e above), the textures reveal a cogenetic origin with the main igneous phases in the sample (interlocking textures, euhedral forms etc; Figure 2).

\subsection{FEG-SEM Imaging of $\mathrm{ZrO}_{2}$ grains}

A total of 42 of the larger grains, including all that were dated by Moser et al., (2013), were characterized by SE and BSE imaging in order to study grain context, microstructures and to choose targets for EBSD and STEM analyses.

High-magnification (>3000 times), high-contrast BSE imaging reveals that the microstructures of each baddeleyite target are highly variable. These range from (a) grains with banded BSE textures, (b) smooth, featureless domains, (c) highly fractured domains, (d) patchy domains with cloudy BSE textures, and (e) domains that are granular at the scale of hundreds of nanometers to micrometers. Typically, several of these different BSE textures are observed within a single grain (e.g. Feature 2451; Figure 3A and 3B). As noted by Moser et al. (2013), thin $(<2 \mu \mathrm{m})$ zircon rims are also present on many of the grains, identified originally by X-ray mapping. Where present, these zircon rims are discontinuous and patchy, typically occurring along contacts with granular clinopyroxene, symplectites or melt veins and pockets (e.g. Figure 3). In many cases, the secondary zircon also fills thin fractures within the baddeleyite.

The CL response of imaged grains is also highly variable. Moser et al. (2013) reported oscillatory growth banding in baddeleyite G16, which was also studied in this investigation. Other grains with similar banding, typical of igneous baddeleyite, include G15, 378 (Figure 4), 2158, 2179. However, other grains display simpler, broader planar banding (e.g. Feature 2451; Figure 3), or cloudy CL textures with little discernable banding (e.g. Feature 1983), or a patchy response corresponding to granular domains (e.g. Feature 2158; Figure 5). As per the BSE textures, both oscillatory banding and cloudy or patchy CL textures have been observed from distinct domains of individual grains (e.g. Feature 378; Figure 3C). 
EBSD analyses were performed on 15 grains that represent a range of the microstructural states observed by SE, BSE and CL imaging. In addition to providing quantitative measurement of lattice orientation, electron diffraction patterns are sensitive to lattice disorder. This is well expressed by band contrast (BC), a quality factor that describes the average intensity of the Kikuchi bands with respect to the overall intensity within the Electron Backscatter Pattern (EBSP). As shown in Figure 4D for Feature 378 the crystallinity of baddeleyites in NWA 5298 is variably degraded, with band contrast values for Feature 378 similar to those of surrounding maskelynite $(<50)$. Such degradation of crystallinity is common to all analyzed grains, although highly variable in magnitude. Even within Feature 378, there are sub- $\mu \mathrm{m}$ scale areas of higher band contrast that are indexed as baddeleyite (Figure 4E; Phase Map). These areas correspond to granular domains observed by SE/BSE/CL imaging. There is no discernable preferred orientation of these diffracting, granular domains, as shown by texture component maps of lattice orientation relative to a reference pixel (cross; Figure 4F). All of the higher band contrast areas of $\mathrm{ZrO}_{2}$ are indexed as baddeleyite (monoclinic). No evidence for preservation of higher-pressure or temperature polymorphs of $\mathrm{ZrO}_{2}$ (e.g. ortho I, tetragonal, ortho II, tetragonal, cubic structures; Ohtaka et al., 2001) have yet been recognized from our EBSD data.

Although there is a large degree of variability in EBSD results between grains, as well as within individual grains, it is possible to define three end-member groupings for the nano- to microstructural state of analyzed grains, as detailed below.

\subsubsection{Group 1: smooth BSE, oscillatory or planar CL banding, crystalline with relict twinning}

A number of baddeleyite grains with smooth or oscillatory CL textures do diffract well, with higher band contrast values than Features 378 and G16. Such grains include Features 1983, 2179 and 2451. Figure 3 displays a range of data for Feature 2451. This baddeleyite occurs within a band of Fe-Ti-oxides (predominantly titanomagnetite), and adjacent to spherulitic maskelynite (Figure 3A). It has a smooth BSE texture, and a bright blue rim in CL with faint linear banding in the grain interior Figure 3B and 3C). 
titanomagnetite, but highly variable on length scales of $\sim 100 \mathrm{~nm}$. The highest band contrast domains form a series of bands that index as baddeleyite (Figure 3E and 3F). These domains all have a similar crystallographic orientation. Where they diffract well enough to be indexed, the domains in between these bands index as baddeleyite with either a $\sim 45^{\circ}$ or $\sim 90^{\circ}$ relative misorientation (Figure $3 \mathrm{~F}$ ). In Features 1983 and 2179 , bands with $0^{\circ}, \sim 45^{\circ}$ and $\sim 90^{\circ}$ relative misorientation are more continuous (higher band contrast and more completely indexed). Baddeleyites in terrestrial magmas have ubiquitous twinning on $\{100\}$ and $\{110\}$, both of which can be polysynthetic. Accordingly, the observed bands are considered relict twin domains that have variably degraded crystallinity. It should be noted that there are smooth gradients of up to $8^{\circ}$ of misorientation within a single twin domain (e.g. Figure 3F), reflecting plastic deformation of the crystal causing lattice rotation.

All Group 1 grains occur within clinopyroxene, pyroxferroite breakdown material (PBM; symplectites; e.g. Feature 1983), titanomagnetite (e.g. Feature 2451) or mesostasis (Feature 2079): mineral phases of relatively high shock impedance.

\subsubsection{Group 2: smooth BSE, oscillatory CL, quasi-amorphous}

Features 378 (Figure 4), G16 and 2158 are representative of grains or domains of individual grains that show well-developed oscillatory CL textures (Figure 4C), but are quasi-amorphous at the scale of the interaction volume for EBSD analysis (few tens of nanometers depth; Figure 4D). Each of these grains contain domains that have as little crystallographic order as the host maskelynite (glass) at the scale of EBSD analysis. However, in all cases these grains do contain some sub- $\mu \mathrm{m}$ domains with higher band contrast values (e.g. Figure 4D and 4E). These index as baddeleyite, and each have highly variable crystallographic orientation relative to any neighboring baddeleyite crystallites.

Grains typical of Group 2 microstructures occur at grain boundaries between clinopyroxene and maskelynite (e.g. Features 378 and G16) or grain boundaries between clinopyroxene and phosphates or titanomagnetite (e.g. Features 1961 and 2158). 
The third end-member grouping is characterized by granular baddeleyite textures, as observed in SE/BSE imaging. These grains include Features 2158 and G1, as well as domains within other grains, such as Feature 378 (Figure 4F). Figure 5 presents a range of data for Feature 2158, which is typical of this group. Sub- $\mu \mathrm{m}$ scale crystallites are clearly discernable in SE and BSE images, notably in the upper grain. The nano-crystalline regions have cloudy CL textures, whereas the area of the lower grain that is smoother in the SE image has a brighter, banded CL texture (Figure 5A and $6 \mathrm{~B}$ ). The band contrast data for this Feature is highly variable on length-scales of hundreds of nanometers. The nanocrystalline domain generally has higher band contrast, and has a higher percentage of indexing than the smooth, bright CL domain (Figure 5C). However, in contrast to Group 2, these baddeleyite nano-crystals have no discernable preferred orientation: with neighboring crystallites having up to $110^{\circ}$ of relative misorientation (Figure 5D). Similar textures, on a $\mu \mathrm{m}$-scale, are observed in the surrounding clinopyroxene crystals (Figure 5E)

Feature 2158 emphasizes the high degree of microstructural variation both within individual grains and between baddeleyite grains that are separated by only a few $\mu \mathrm{m}$ in the sample. Note that the smooth, bright CL and largely quasi-amorphous domain in Feature 2158 (similar to Group 1 Features) occurs where the grain is surrounded by Fe-Ti-oxides.

The granular grains with Group 3 microstructures occur in a range of petrological settings in the thin section. These include grains at the boundaries between clinopyroxene and impact melt pockets (e.g. Features G1 and G7), enclosed within vesicular plagioclase melt (e.g. Feature G5) and within granular domains of clinopyroxene (e.g. Feature 2158). Accordingly, grains with Group 3 microstructures are associated with impact melt (plagioclase or phosphate dominated) or with high-temperature recrystallization resulting from impact heating. It should be noted that these grains are not exclusively found within impact melt pockets.

\subsubsection{Zircon rims}

Rims or patches of zircon occur at the margins of most analyzed $\mathrm{ZrO}_{2}$ grains, including examples from each of the three microstructural groupings discussed above. The zircon occurs as less than $2 \mu \mathrm{m}$ patches (often sub $\mu \mathrm{m}$ ) that are discontinuous. Zircon growth is most prominent at the margins of baddeleyites 
that are clearly in contact with melt. This includes grain boundaries in contact with quenched shock melt pockets (e.g. Feature G16), as well as contacts with melt veins of maskelynite (e.g. Feature 2179) and spherulitic maskelynite (e.g. Feature 378; Figure 3)

High magnification SE and BSE imaging of the zircon rims failed to show any evidence of shock microstructures such as planar features or curviplanar features. EBSD data was acquired for zircon rims from 9 baddeleyite grains. In all cases, the zircon-rims diffract much more strongly than the baddeleyite, with high band contrast values $(>100)$. They are comprised of multiple crystals on the hundreds of nanometer to $\mu \mathrm{m}$ scale (e.g. Figure 3E), with highly variable crystallographic orientations. Misorientation values between neighboring grains within a zircon rim are as high as $100^{\circ}$. In several cases (e.g. Features 2 and 550, 1924, 2455), smooth misorientation gradients up to $4^{\circ}$ occur across individual zircon crystals. This is significant given that the minimum angular resolution of our method is on the order of $1^{\circ}$ (Moser et al., 2011), and requires low-degree plastic deformation after growth.

\subsection{Scanning Transmission Electron Microscopy (STEM)}

STEM imaging was performed on a FIB liftout from Feature 378, a Group 2 grain that appears quasiamorphous at the 2D length-scale resolution of conventional EBSD spatial resolution (ca. $80 \times 40 \mathrm{~nm}$ ), as it does not produce resolvable Kikuchi bands that can be indexed. As shown in Figure 6, however, this grain at its core is crystalline but has a complex lattice structure at length-scales of, at most, a few tens of nanometres. This includes $<50 \mathrm{~nm}$ wide planar features. Closer to the grain margins these features are interrupted by a mosaic of crystal domains up to hundreds of nanometers across: similar to those recorded by original EBSD of the surface of this grain. Accordingly, the grain is largely nanocrystalline, with crystalline domains separated by low angle grain boundaries or transitional zones of weak ordering. Zircon rims at the contact between baddeleyite and maskelynite have, despite their irregular shape, a uniform lattice orientation across the rim width of tens to hundreds of nanometers. They do not share the baddeleyite shock nanostructure, and no other characteristics of shocked zircons such as planar features or microtwins have been observed. 


\section{Discussion}

Our results show a remarkable diversity of $\mathrm{ZrO}_{2}$ micro- to nano-structures within a single thin section. The petrological setting, micro-texture, trace element zonation (from CL), crystallinity and crystal structure all vary between and within individual grains. These variations are much more diverse, and with a far higher degree of structural reordering than seen in baddeleyites subjected to experimental shockloading of up to $57 \mathrm{GPa}$ (Niihara et al., 2012). As noted for other mineral phases (e.g. quartz; Grieve and Langenhorst, 1996), the timescales of shock compression and decompression in experiments (microseconds) are much shorter than in large natural impact events (seconds), which can be critical for phase transitions and structural damage to target phases. Moreover, Niihara et al. (2012) caution that the higher porosity of their experimental materials could compromise a direct comparison to natural systems. The phenomena observed in $\mathrm{ZrO}_{2}$ grains within NWA 5298 are consistent with reactions to different maskelynite etc), which indicate that the rock experienced a major shock-metamorphic event with pressures in excess of $30 \mathrm{GPa}$. Consideration of the three recognized end-member micro- to nanostructural states among the analyzed grains (Groups 1, 2 and 3) allows for a reconstruction of a shock microstructural sequence in the sample.

The Group 1 grains display smooth BSE textures and oscillatory or planar CL banding typical of baddeleyites found in terrestrial igneous rocks (Moser et al., 2013; Rodionov et al., 2012). These grains also preserve evidence of polysynthetic twinning, as shown by bands of baddeleyite with $45^{\circ}$ or $90^{\circ}$ relative misorientation (e.g. Figure 3F). Accordingly, the Group 1 grains preserve multiple features shared by baddeleyite crystals grown in terrestrial magmas, and are thus considered to be the least affected by shock metamorphism in the studied sample. This is consistent with the fact that they are located within mineral phases of relatively high shock impedance (e.g. pyroxene, titanomagnetite). There is, however, evidence of crystal-plastic strain within these baddeleyite grains, as evidenced by lattice misorientation of up to $8^{\circ}$ within individual twin domains. Similar deformation has been observed within shocked terrestrial 
and lunar zircon, where it has been associated with relatively late stage shock decompression at high temperatures and high-strain rates (Moser et al., 2011; Timms et al., 2012).

Degraded crystallinity is common to many of the analyzed grains, and the Group 2 grains are quasiamorphous at the length scales of EBSD mapping at maximum resolution (ca. $60 \mathrm{~nm}$ ). High-pressure phase transformation of baddeleyite to denser orthorhombic polymorphs occur at pressures as low as 3 GPa (Ohtaka et al., 2011). These polymorphs are thought to be non-quenchable, in which case inversion to a low-pressure disordered phase (diaplectic glass) would be expected during decompression. However, crystalline domains of material at the single to tens of nanometer scale are evident from STEM imaging (Figure 6). No high-pressure $\mathrm{ZrO}_{2}$ polymorphs have been identified from the EBSD data of this study, but high-resolution diffraction experiments by TEM or synchrotron X-ray techniques will be required to resolve whether high-pressure phases are preserved at the nanometer scale. Particularly given the evidence for widespread melt-formation (impact melt pockets and vesicular plagioclase melts) in this rock, it is likely that these crystallites were formed by decompression at elevated temperatures immediately following the shock-event, providing energy for partial back transformation to monoclinic crystal structure. This process would be expected to produce polycrystalline aggregates of baddeleyite at higher temperatures and hence more prolonged heating durations (seconds to minutes; El Goresy et al., 2013).

The granular grains of Group 3 (e.g. Features 2158 and G1) are likely to be product of this process, as they contain an apparently random orientation of nano- to micro-scale crystallites of baddeleyite. The granular textures are clearly a relatively late stage feature, given that they overprint pre-existing grain morphologies. These granules may well be a coarser grained equivalent of the single nanometer scale crystalline patches observed in the STEM data from a Group 2 grain (Feature 378), suggesting more prolonged or intensive impact heating was responsible for their formation. This is supported by the fact that Group 3 grains are spatially associated with impact-melt or recrystallized clinopyroxene.

These observations provide a shock nano- to micro-structural sequence for the sample (Figure 7), comprising: (1) plastically deformed baddeleyite grains that preserve relict twinning and trace element zonation typical of igneous baddeleyites; (2) disordered $\mathrm{ZrO}_{2}$ that is quasi-amorphous at the scale of tens of nanometers; (3) granular baddeleyite created by decompression at high temperatures and 
recrystallization; and (4) post-shock reaction of $\mathrm{ZrO}_{2}$ grains along marginal contacts with melt or fluid to form zircon, which also undergoes minor deformation during cooling after launch. It is important to note that the entire duration for these processes to occur is order of seconds to minutes, from the moment of impact to final cooling (Shaw and Walton, 2013).

Another important observation from our study is that location appears to be critical to the preserved microstructural state of baddeleyite grains within the rock. Grains separated by as little as $10 \mu \mathrm{m}$ have very different textural and structural characteristics at the scales of microns to tens of nanometers (e.g. Figure 5). This indicates that the shock pressure and post-shock temperature experienced by individual grains varied dramatically, even over such small length scales. Shock wave propagation in heterogeneous materials is a very complex process, and it is well known that the loading paths and peak shock pressures experienced by individual crystals can vary dramatically. This is caused by shock-wave interactions, such as refraction and reflection, at boundaries between minerals of different shock impedance, as well as collisions between refracted shock fronts that can produce localized pressure spikes. As a result, the peak shock pressure and waste heat experienced on the micrometer-scale can vary by a factor of two or more (Sharp and DeCarli. 2006). The results of these variations can be dramatic. For example in Feature 2158 a baddeleyite partially surrounded by a high impedance phase (titanomagnetite) preserves Group 2 shock characteristics, whereas a grain ca. $10 \mu \mathrm{m}$ away within clinopyroxene has a granular texture typical of Group 3 characteristics. More generally, there is a clear linkage between microstructural grouping and petrological setting of the baddeleyite grains; Group 1 grains occur within mineral phases of relatively high shock-impedance (e.g. clinopyroxene and titanomagnetite), Group 2 grains typically occur at the boundaries between phases of differing shock impedance (e.g. clinopyroxene and plagioclase), and Group 3 grains are spatially associated with impact melt or areas of widespread recrystallization.

\subsection{Shock effects on U-Pb isotope ratios in baddeleyite and the age of NWA 5298}

Combining the detailed nano- to microstructural analysis of baddeleyite grains with SIMS U-Pb isotope measurements of Moser et al., (2013), provides a new level of understanding into mechanisms of agedisturbance in shocked baddeleyite. Linkages between these datasets are summarized in Figure 8. 
Grains with Group 1 microstructural characteristics yield the oldest ${ }^{206} \mathrm{~Pb} / 238 \mathrm{U}$ dates: ranging from $227 \pm$ $18 \mathrm{Ma}$ (Feature 2457) to $153 \pm 9 \mathrm{Ma}$ (Feature G15). These four grains preserve multiple attributes of baddeleyites grown in terrestrial magmas, including oscillatory or planar CL banding and newly identified relict polysynthetic twinning, are texturally cogenetic with host igneous mineral phases, and contain the highest proportions of radiogenic $\mathrm{Pb}$ among the analyzed grains $\left(206 \mathrm{~Pb}_{\text {rad }}=69\right.$ to $97 \%$; average $\left.=84 \%\right)$. Accordingly, a weighted mean of the five spot analyses of these grains provide the best estimate of magmatic crystallization age for NWA 5298. The resulting ${ }^{206 \mathrm{~Pb}} / 238 \mathrm{U}$ age of $175 \pm 30 \mathrm{Ma}$ is slightly modified from the age of Moser et al., (2013), due to the new grouping based on microstructure, but overlaps with the previous age within uncertainty. This is consistent with numerous Rb-Sr, Sm-Nd and UTh- $\mathrm{Pb}$ mineral isochron dates of ca. $200 \mathrm{Ma}$ from similar basaltic shergottites, including Shergotty, Zagami and Los Angeles (Nyquist et al., 2011) and recent SIMS analyses of U-Pb isotopes in phosphates from Zagami (153 \pm 81 Ma; Zhou et al., 2013) and baddeleyites in Roberts Massif 04261 (ca. 200 Ma; Niihara, 2011) and Zagami (182.7 \pm 6.9 Ma; Zhou et al., 2013).

The quasi-amorphous grains with predominantly Group 2 microstructural characteristics yield younger U$\mathrm{Pb}$ ages, with ${ }^{206 \mathrm{~Pb}} /{ }^{238} \mathrm{U}$ dates between $141 \pm 34$ (Feature G16) and ca. $85 \mathrm{Ma}$ (Figure 8). The much lower proportions of radiogenic $\mathrm{Pb}$ in these grains $\left(206 \mathrm{~Pb}_{\mathrm{rad}}=17\right.$ to $68 \%$; average $\left.=40 \%\right)$, together with the fact that the data are spread along the Tera-Wasserburg concordia, indicates these grains have experienced variable degrees of radiogenic Pb-loss. Interestingly, the grains with the weakest electron diffraction (most disordered) have the oldest ages of this group, and preserve the sharpest planar or oscillatory banding in cathodoluminescence (e.g. Feature G16; Figure 8). This suggests that the shock process of disordering of the precursor baddeleyite does not in itself lead to mobilization of $\mathrm{Pb}$ and other trace elements, possibly because this process occurs at timescales of milliseconds to deciseconds (Sharp and DeCarli, 2006). Rather, grains that contain domains of granular baddeleyite yield the younger ages and more cloudy CL textures (Figure 8). Post-shock heating must therefore be critical to enabling Pb-loss and the mobilization of trace elements in the shocked baddeleyites. This is emphasized by the fact that the youngest analyses of all measured grains come from those with Group 3 microstructural characteristics (granular BSE, patchy or cloudy CL and nano- to micro-crystalline). This finding for baddeleyite echoes that observed for zircon, wherein both shock damage and heating/fluids are required to cause Pb-loss during shock metamorphism 
(Krogh et al., 1996). It is also possible that beam overlap with launch-generated zircon rims has contributed to the younger measured ages. However, no clear relationship between the microstructural state of baddeleyite and the volume or width of zircon rims has been identified, with micron-scale overgrowths present on features from each of the microstructural groupings. Furthermore, Schmitt et al. (2010) and Chamberlain et al. (2010) demonstrated that oxygen-flooding techniques minimize matrix and orientation sensitivity in SIMS micro-baddeleyite analyses to levels of error that are much smaller than the uncertainties on the NWA 5298 U-Pb data of Moser et al., (2013), which are dominated by their relatively low $\mathrm{U}$ contents. This is supported by the fact that quasi-amorphous Group 2 grains provide dates that are intermediate between the two groups of crystalline baddeleyite. Accordingly, Pb-loss due to heating and recrystallization of baddeleyite grains, rather than the presence of zircon rims or analytical matrix effects, is considered the dominant control on the younger measured ages. The minor plastic strain $\left(<4^{\circ}\right.$ of crystallographic misorientation) seen in some post-shock zircon reaction granules is ascribed to postlaunch thermal stresses due to cooling and contraction of the meteoroid as it left the Martian atmosphere, volume adjustments as local melt pockets condensed, and pervasive waste heat from shock radiated to space.

The granular Group 3 grains yield ages as young as $22 \pm 2 \mathrm{Ma}$ (Feature G1), placing an upper constraint of the timing of shock metamorphism and the ejection of NWA 5298 from Mars. This constraint on ejection age is consistent with cosmic ray exposure ages for Shergottites of between 0.7 and $20 \mathrm{Ma}$ (Nyquist et al., 2001).

Our new data clearly show that the variation in U-Pb isotope ratios among baddeleyite crystals within NWA 5298 are the result of disturbance by shock metamorphism, but by highly variable degrees that correlate broadly with microstructural state. Within a single thin-section, baddeleyite grains with primary igneous characteristics, and a maximum magmatic crystallization age of $175 \pm 30 \mathrm{Ma}$, occur within hundreds of microns of highly recrystallized granular grains as young as $22 \pm 2 \mathrm{Ma}$. This finding is in contrast to predictions from shock loading and annealing experiments that shock metamorphism does not cause significant disturbance of the U-Pb system in baddeleyite (Niihara et al., 2012), but consistent with the commonly observed variations in peak shock temperatures in natural samples due to grain 
environment, variations in mineral density and shock wave impedance.

\section{Conclusions}

Our micro- to nano-structural measurements of baddeleyite grains in NWA 5298 have revealed a widerange of new shock metamorphic effects on this important chronometer. These have significant implications for the interpretation of $\mathrm{U}-\mathrm{Pb}$ isotopic ages in planetary materials.

- The response of baddeleyite crystals to shock metamorphism within a single thin-section is highly variable on spatial scales down to tens of $\mu \mathrm{m}$. Analyzed grains range from those that preserve primary (magmatic) twinning and zonation (baddeleyite shock Group 1), to quasi-amorphous $\mathrm{ZrO}_{2}$ (Group 2) and to recrystallized granular domains of baddeleyite (Group 3). This range of structural states is controlled to a large extent by the shock impedance of surrounding mineral phases, as well as the extent of post-shock heating.

- The variable shock-features can be explained by a systematic microstructural evolution resulting from a single shock-metamorphic cycle. This includes plastic deformation and amorphization of precursor magmatic baddeleyite caused by shock deformation and phase transformations, followed by recrystallization and zircon-rim growth that is driven by post-shock heating.

- These micro- to nano-structural states correlate closely with previously measured $\mathrm{U}-\mathrm{Pb}$ ages, demonstrating that shock deformation during launch, and consequent heating and melt reaction, has led to variable degrees of $\mathrm{Pb}$ loss.

- The youngest $\mathrm{U}-\mathrm{Pb}$ ages are measured in recrystallized nano- to micro-granular baddeleyite grains (Group 3), indicating that it is post-shock heating and new mineral growth that drives isotopic disturbance, rather than shock deformation and phase transitions. However, there is no evidence for melting of baddeleyite in NWA 5298.

- By linking $\mathrm{U}-\mathrm{Pb}$ isotope analyses of accessory minerals with detailed micro- to nano-structural analyses by FE-SEM, luminescence, EBSD and TEM, our data demonstrates that it is possible to resolve the 
primary magmatic age and timing of impact in highly shocked planetary materials.

445

- The new highly detailed nanostructural analyses support that NWA 5298 is a relatively young (lateAmazonian) basaltic igneous rock. The best estimate of crystallization age is $175 \pm 30 \mathrm{Ma}$, and the meteorite was ejected from Mars by an impact event $<22 \pm 2$ Ma.

The highly variable shock-induced age resetting of baddeleyite in NWA 5298 provides both a cautionary tale and exciting new opportunities for Solar System chronology. Firstly, it cannot be assumed that baddeleyites will always provide magmatic crystallization ages from highly shocked achondrites, and careful nano- to micro-structural analysis of individual grains is required to aid interpretation of measured ages. Secondly, our data demonstrate that if this careful work is done, it is possible to resolve the timing of magmatic crystallization from that of shock resetting, thereby providing insights into both lithospheric processes and the impact history of planetary bodies. In the case of shergottites, this analysis has revealed that at least some of these rocks were formed by relatively recent ( $<200 \mathrm{Ma})$ volcanism on Mars.

\section{Acknowledgements}

J. Darling gratefully acknowledges support from Foreign Affairs and International Trade Canada (DFAIT) in the form of a Canadian Commonwealth Post-Doctoral Research Fellowship, and to the Centre for Planetary Science and Exploration for a CPSX Fellowship. An NSERC Discovery Grant to D. Moser is acknowledged as are contributions from Matthieu Bugnet and Julia Huang with regard to STEM analysis and lift-out fabrication, respectively, at the Canadian Centre for Electron Microscopy, McMaster University. David Gregory is thanked for generous sample access, as is Dr. Tony Irving (University of Washington) for providing valuable insights into shergottite igneous and shock textures. We thank the editor and three anonymous reviewers for their contributions.

\section{Figure and Table Captions}

Figure 1: The studied thin section of NWA 5298. (A) Transmitted plain-polarized light image of the whole 
thin section and higher magnification inset showing typical textures of zoned and fractured clinopyroxene (cpx), example planar features in cpx (arrows), maskelynite (mask), vesicular plagioclase melt (vpm) and shock-melt pockets (dark; smp). The locations of identified $\mathrm{ZrO}_{2}$ grains, with surface areas between 40 and $500 \mu \mathrm{m}^{2}$, are shown by open circles on the higher magnification image ( $\mathrm{n}=18$ in the field of view).

Figure 2: Examples of igneous and shock-metamorphic petrological features in the studied thin section. The bright phase in the centre of each BSE image is the numbered $\mathrm{ZrO}_{2}$ feature. A) Impact melt pocket (right of image), granularization of clinopyroxene (cpx) and lamellae of cpx within spherulitic maskelynite (mask2); (B) $\mathrm{ZrO}_{2}$ grain within titanomagnetite (ttm), surrounded by two distinct types of maskelynite (mask1 and mask2); (C) complex domain including cpx with pyroxferroite breakdown material (PBM) symplectites and granularization, impact melt, phosphates and vesicular plagioclase melt; (D) zone of PBM within cpx, with melt vein of mask2 and cpx lamellae within mask2; (E) $\mathrm{ZrO}_{2}$ grain within PBM and at the boundary between cpx and mask2; (F) baddeleyite grain within mesostasis, highlighting the difference between microcrystalline mesostasis, plagioclase melt (mask 2) and quenched impact melt.

Figure 3: Summary of nano- to micro-structural results for Feature 2451: typical of Group 1 grains. A) BSE image showing grain location partially within titanomagnetite; (B) high-contrast BSE image of the $\mathrm{ZrO}_{2}$ grain; (C) CL image showing broad planar banding and bright rim; (D) EBSD band contrast map showing variable diffraction intensity within $\mathrm{ZrO}_{2}$ grain, and lack of order within surrounding maskelynite, pixel size is $100 \mathrm{~nm}$; (E) distribution of phases based upon indexing of EBSD data; (F) texture component map for baddeleyite, showing crystallographic orientation relative to a reference pixel (white cross).

Figure 4: Summary of nano- to micro-structural results for Feature 378: typical of Group 2 grains. A) BSE image showing grain location at boundary between cpx and mask2; (B) high-contrast BSE image of the $\mathrm{ZrO}_{2}$ grain, highlighting granular domains and zircon rim; (C) CL image showing fine oscillatory and planar banding in some domains, and cloudy textures in granular domains; (D) EBSD band contrast map showing the lack of order within the $\mathrm{ZrO}_{2}$ grain, except for granular domains (pixel size is $150 \mathrm{~nm}$ ); (E) distribution of baddeleyite and zircon based upon indexing of EBSD data; (F) texture component map for baddeleyite. 
Figure 5: Summary of nano- to micro-structural results for feature 2158. A) BSE image showing location of 2 grains within granular cpx (upper granular textured $\mathrm{ZrO}_{2}$ grain typical of Group 3 grains) and partially enclosed by titanomagnetite (lower, smooth textured grain with Group 2 characteristics); (B) CL image showing cloudy texture within the upper grain and brighter, banded texture within the lower grain; (C) EBSD band contrast map showing the highly variable level of order within the two $\mathrm{ZrO}_{2}$ grains (pixel size is $100 \mathrm{~nm}$ ); (D) texture component map for baddeleyite, showing highly variable crystallographic orientation of baddeleyite crystallites; (E) texture component map for clinopyroxene, showing a similar granular texture to the baddeleyite crystallites.

Figure 6: A HAADF (STEM) image of a focused ion beam (FIB) lift-out from baddeleyite Feature 378 (location inset). Greyscale variations correspond to differences in atomic number (high $\mathrm{Z}=$ bright) as well as orientation nanostructure. Phase identification is based on earlier EBSD data from the surface around the liftout, and on EDS analysis of the foil while in STEM mode. Note the complex linear features and local granular domains with orientation variations in $\mathrm{ZrO}_{2}$. The linear orientation variations are at lengthscales less than the diffraction area for individual EBSD analysis spots (ca. $80 \mathrm{~nm}$ in the beam direction, see box), and the trend of these tends to be overprinted by larger crystalline subgrain domains. Note also the relatively structure-less maskelynite and zircon rims.

Figure 7: Micro- to nano-structural grouping of shocked baddeleyite grains in NWA 5298, with the interpreted microstructural evolution resulting from shock deformation, transformation and post-shock heating. The stylized baddeleyite grains summarize the progression of microstructural states, from an ideal magmatic precursor grain (greys $=$ crystalline, monoclinic $\mathrm{ZrO}_{2}$; white $=$ quasi-amorphous $\mathrm{ZrO}_{2}$ ). Features with dominant characteristics of specific groups are listed $(n=25$; features with U-Pb data from Moser et al., 2013 in italic).

Figure 8: Marriage of imaging, microstructure and U-Pb isotope data for baddeleyite grains in NWA 5298, showing a systematic relationship between micro- to nano-structural state and measured age for the baddeleyite population. Examples are shown of Features from each microstructural grouping.: Group 1: smooth BSE, oscillatory or planar CL banding, crystalline with relict twinning; Group 2: smooth BSE, oscillatory CL, quasi-amorphous; Group 3: granular BSE, patchy or cloudy CL and nano- to micro- 
crystalline. ${ }^{206 \mathrm{~Pb} /}{ }^{238} \mathrm{U}$ ages are shown for each feature $(2 \sigma$ uncertainties), along with the measured percentage of radiogenic ${ }^{206} \mathrm{~Pb}\left({ }^{206} \mathrm{~Pb}_{\text {rad }}\right)$, and the approximate analytical area (red box) during SIMS analysis by Moser et al., (2013). Images of Feature G16 are from Moser et al., (2013).

Table 1: Instrument, data collection and data processing settings for EBSD analyses.

\section{References}

Aramovich, C.J., Herd, C.D.K., Papike, J.J., 2002. Symplectites derived from metastable phases in martian basaltic meteorites. American Mineralogist 87, 1351-1359.

Borg, L.E., Nyquist, L.E., Wiesmann, H., Reese, Y., 2002. Constraints on the petrogenesis of Martian meteorites from the Rb-Srand $\mathrm{Sm}-\mathrm{Nd}$ isotopic systematics of the lherzolitic shergottites ALH77005 and LEW88516. Geochimica et Cosmochimica Acta 66, 2037-2053.

Borg, L.E., Nyquist, L.E., Wiesmann, H., Shih, C.-Y., Reese, Y., 2003. The age of Dar al Gani 476 and the differentiation history of the martian meteorites inferred from their radiogenic isotopic systematics. Geochimica et Cosmochimica Acta 67, 3519-3536.

Bouvier, A., Blichert-Toft, J., Albarede, F., 2009. Martian meteorite chronology and the evolution of the interior of Mars. Earth and Planetary Science Letters 280, 285-295.

Bouvier, A., Blichert-Toft, J., Vervoort, J.D., Gillet, P., Albarède, F., 2008. The case for old basaltic shergottites. Earth and Planetary Science Letters 266, 105-124.

Bouvier, A., Blichert-Toft, J., Vervoort, J., Albarede, F., 2005. The age of SNC meteorites and the antiquity of the Martian surface. Earth and Planetary Science Letters 240, 221-233.

Chamberlain, K.R., Schmitt, A.K., Swapp, S.M., 2010. In situ U-Pb SIMS (IN-SIMS) micro-baddeleyite dating of mafic rocks: method with examples. Precambrian Research 183, 379-387. 
Chen, M., El Goresy, A., 2000. The nature of maskelynite in shocked meteorites: not diaplectic glass but a glass quenched from shock-induced dense melt at high pressures. Earth and Planetary Science Letters 179, 489-502.

El Goresy, A., Gillet, P., Miyahara, M., Ohtani, E., Ozawa, S., Beck, P., Montagnac, G., 2013. Shockinduced deformation of Shergottites: Shock-pressures and perturbations of magmatic ages on Mars. Geochimica et Cosmochimica Acta 101, 233-262.

Grieve, R.A.F., Langenhorst, F., Stöffler, D., 1996. Shock metamorphism of quartz in nature and experiment: II. Significance in geoscience. Meteoritics and Planetary Science 31, 6-35.

Heaman, L., 2009. The application of U-Pb geochronology to mafic, ultramafic and alkaline rocks: An evaluation of three mineral standards. Chemical Geology 261, 43-52.

Hui, H., Peslier, A.H., Lapen, T.J., Shafer, J.T., Brandon, A.D., Irving, A.J., 2011. Petrogenesis of basaltic shergottite Northwest Africa 5298: Closed-system crystallization of an oxidized mafic melt. Meteoritics \& Planetary Science 46, 1313-1328.

Ikeda, Y. et al., 2006. Petrology of a new basaltic shergottite: Dhofar 378. Antarctic Meteorite Research $19,20-24$.

Irving A.J., Kuehner S.M., 2008. Northwest Africa 5298: A strongly shocked basaltic Shergottite equilibrated at QFM and high temperature (abs\#5332). Meteoritics \& Planetary Sciences 43, A63.

Irving, A.J. et al., 2011. Petrologic, elemental and isotopic characterization of shock melted enriched ultramafic shergottite Northwest Africa 6342. Lunar Planet.Sci. 42. Abstract \#1612.

Jagoutz, E., Wanke, H., 1986. Sr and Nd isotopic systematics of Shergotty meteorite. Geochimica et Cosmochimica Acta 50, 939-953.

Jiang, Y., Hsu, W., 2012. Petrogenesis of Grove Mountains 020090: An enriched “lherzolitic” shergottite. 
Jones, J.H., 1986. A discussion of isotopic systematics and mineral zoning in the shergottites: Evidence for a 180 m.y. igneous crystallization age. Geochimica et Cosmochimica Acta 50 (6), 969-977.

Krogh, T.E., Kamo, S.E., Bohor, B.F., 1996. Shock metamorphosed zircons with correlated U-Pb discordance and melt rocks with concordant protolith ages indicate an impact origin for the Sudbury structure. Monograph American Geophysical Union 95, 343-353.

Krot, A.N., Rubin, A.E., Kononkova, N.N., 1993. First occurrence of pyrophanite (MnTiO3) and baddeleyites (ZrO2) in an ordinary chondrite. Meteoritics and Planetary Science 28, 232-252.

Marti, K., Kim, J.S., Thakur, A.N., McCoy, T.J., Keil, K., 1995. Signatures of the Martian atmosphere in glass of the Zagami meteorite. Science 267, 1981-1984.

Meyer, C., 2012. Martian Meteorite Compendium. curator.jsc.nasa.gov. URL http://curator.jsc.nasa.gov/antmet/mmc/index.cfm (accessed 7.23.14).

Moser, D.E., Chamberlain, K.R., Tait, K.T., Schmitt, A.K., Darling, J.R., Barker, I.R., Hyde, B.C., 2013. Solving the Martian meteorite age conundrum using micro-baddeleyite and launch-generated zircon. Nature 499, 454-457.

Moser, D.E., Cupelli, C.L., Barker, I.R., Flowers, R.M., Bowman, J.R., Wooden, J., Hart, J.R., 2011. New zircon shock phenomena and their use for dating and reconstruction of large impact structures revealed by electron nanobeam (EBSD, CL, EDS) and isotopic U-Pb and (U-Th)/He analysis of the Vredefort dome. Canadian Journal of Earth Sciences 48, 117-139.

Niihara, T., 2011. Uranium-lead age of baddeleyite in shergottite Roberts Massif 04261: Implications for magmatic activity on Mars. Journal of Geophysical Research: Planets 116, E12008.

Niihara, T., Kaiden, H., Misawa, K., Sekine, T., Mikouchi, T., 2012. Earth and Planetary Science Letters. Earth and Planetary Science Letters 341-344, 195-210. 
Nyquist, L.E., Bogard, D.D., Shih, C.Y., Greshake, A., Stoffler, D., Eugster, O., 2001. Ages and geologic histories of Martian meteorites. Space Science Reviews 96, 105-164.

Nyquist, L.E., Bogard, D.D., Shih, C.Y., Park, J., 2009. Concordant Rb-Sr, Sm-Nd, and Ar-Ar ages for Northwest Africa 1460: A 346Ma old basaltic shergottite related to "Iherzolitic" shergottites. Geochimica et Cosmochimica Acta 73, 4288-4309.

Ohtaka, O., Fukui, H., Kunisada, T., Fujisawa, T., Funakoshi, K., Utsumi, W., Irifune, T., Kuroda, K., Kikegawa, T., 2001. Phase relations and equations of state of $\mathrm{ZrO} 2$ under high temperature and high pressure. Physical Review B 63, 174108.

Rodionov, N.V., Belyatsky, B.V., Antonov, A.V., Kapitonov, I.N., Sergeev, S.A., 2012. Comparative insitu U-Th-Pb geochronology and trace element composition of baddeleyite and low-U zircon from carbonatites of the Palaeozoic Kovdor alkaline-ultramafic complex, Kola Peninsula, Russia. Gondwana Research 21, 728-744.

Schmitt, A.K., Chamberlain, K.R., Swapp, S.M., Harrison, T.M., 2010. In situ U-Pb dating of microbaddeleyite by secondary ion mass spectrometry. Chemical Geology 269, 386-395.

Sharp, T.G. and DeCarli, P.S., 2006. Shock effects in meteorites. Meteorites and the early Solar System II 653-677.

Shaw C. S. J. and Walton E. L., 2013. Thermal modeling of shock melts in Martian meteorites: implications for preserving Martian atmospheric signatures and crystallization of high-pressure minerals from shock melts. Meteorit. Planet. Sci. 48, 758-770.

Shih, C.Y., Nyquist, L.E., Bogard, D.D., McKay, G.A., 1982. Chronology and petrogenesis of young achondrites, Shergotty, Zagami, and ALHA77005: Late magmatism on a geologically active planet. Geochimica et Cosmochimica Acta 46, 2323-2344.

Stöffler D., Ostertag R., Jammes C., Pfannschmidt G., Sen Gupta P. R., Simon S. B., Papike J. J., and Beauchamp R. H. 1986. Shock metamorphism and petrography of the Shergotty achondrite. 
Timms, N.E., Reddy, S.M., Healy, D., 2012. Resolution of impact-related microstructures in lunar zircon: A shock-deformation mechanism map. Meteoritics \& Planetary Science.47, 120-141.

Wang, D., Chen, M., 2006. Shock-induced melting, recrystallization, and exsolution in plagioclase from the Martian lherzolitic shergottite GRV 99027. Meteoritics and Planetary Science 41, 519-527.

Wang Y., Hsu W., Guan Y., Li X., Li Q., Liu Y., and Tang G. 2012. Petrogenesis of the Northwest Africa 4734 basaltic lunar meteorite. Geochimica et Cosmochimica Acta 92, 329-344.

Walton, E.L. et al., 2009. Extreme shock effects in relatively enriched shergottite Northwest Africa 4797. Lunar Planet. Sci. 40. Abstract \#1464.

Warren, P.H., Greenwood, J.P., Rubin, A.E., 2004. Los Angeles: A tale of two stones. Meteoritics and Planetary Science 39, 137-156.

Werner, S.C., Ody, A., Poulet, F., 2014. The Source Crater of Martian Shergottite Meteorites. Science, 343, 1343-1346.

Zhou, Q., Herd, C.D.K., Yin, Q.-Z., Li, X.-H., Wu, F.-Y., Li, Q.-L., Liu, Y., Tang, G.-Q., McCoy, T.J., 2013. Earth and Planetary Science Letters. Earth and Planetary Science Letters 374, 156-163. 
Highly variable response of baddeleyite to shock metamorphism in young basaltic shergottite NWA 5298 and implications for Solar System chronology

James R. Darlinga*, Desmond E. Moser ${ }^{\mathrm{b}}$, Ivan R. Barker ${ }^{\mathrm{b}}$, Kim T. Tait ${ }^{\mathrm{c}}$, Kevin R. Chamberlain ${ }^{\mathrm{d}}$, Axel K. Schmitte and Brendt C. Hyde

Highlights:

- Nanoanalysis reveals a wide range of new shock-metamorphic phenomena in baddeleyite.

- Systematic microstructural evolution in baddeleyite from a single shock event.

- Shock microstructures correlate with the degree of $\mathrm{U}-\mathrm{Pb}$ age resetting.

- A refined crystallization age for NWA 5298 of $175 \pm 30 \mathrm{Ma}$.

- At least some shergottites record relatively recent ( $<200 \mathrm{Ma})$ volcanism on Mars. 
A) Transmitted

light
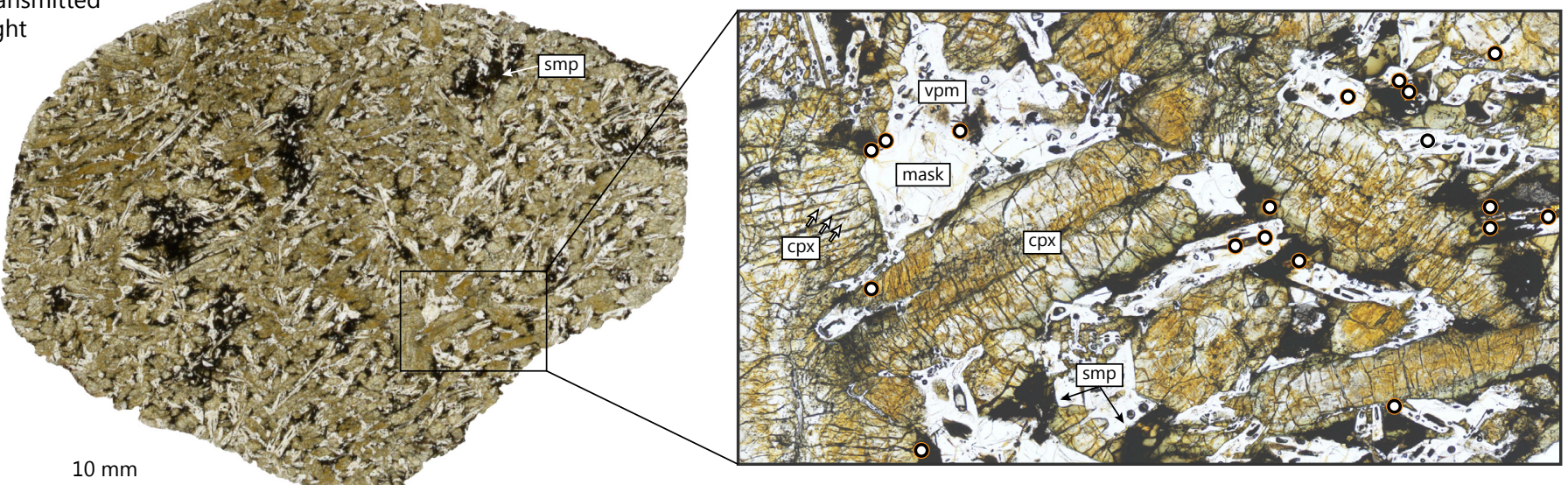

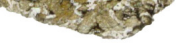




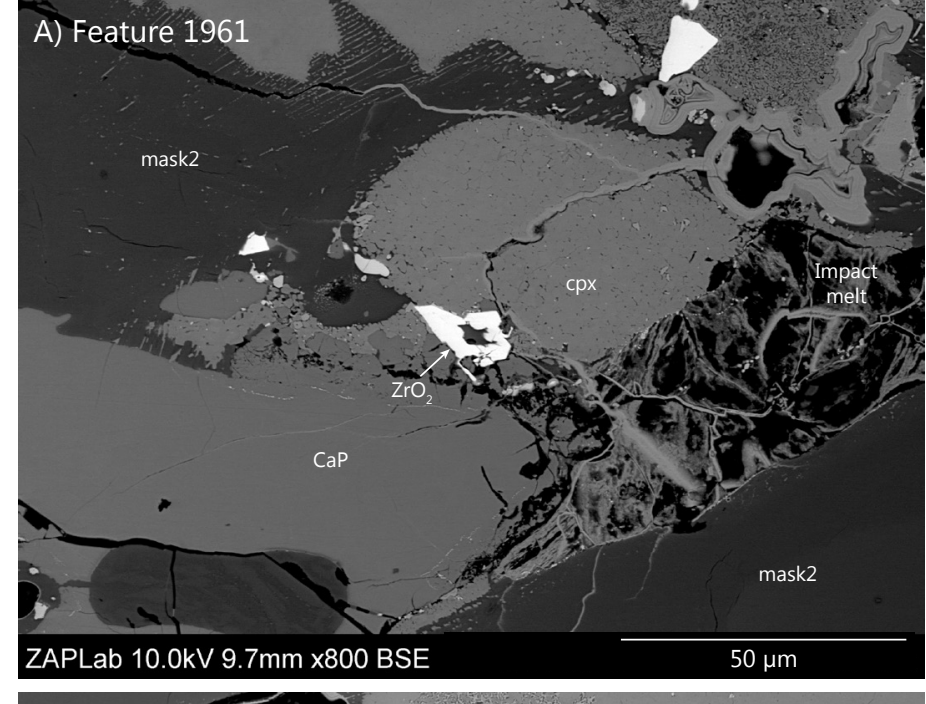

B) Feature 2451

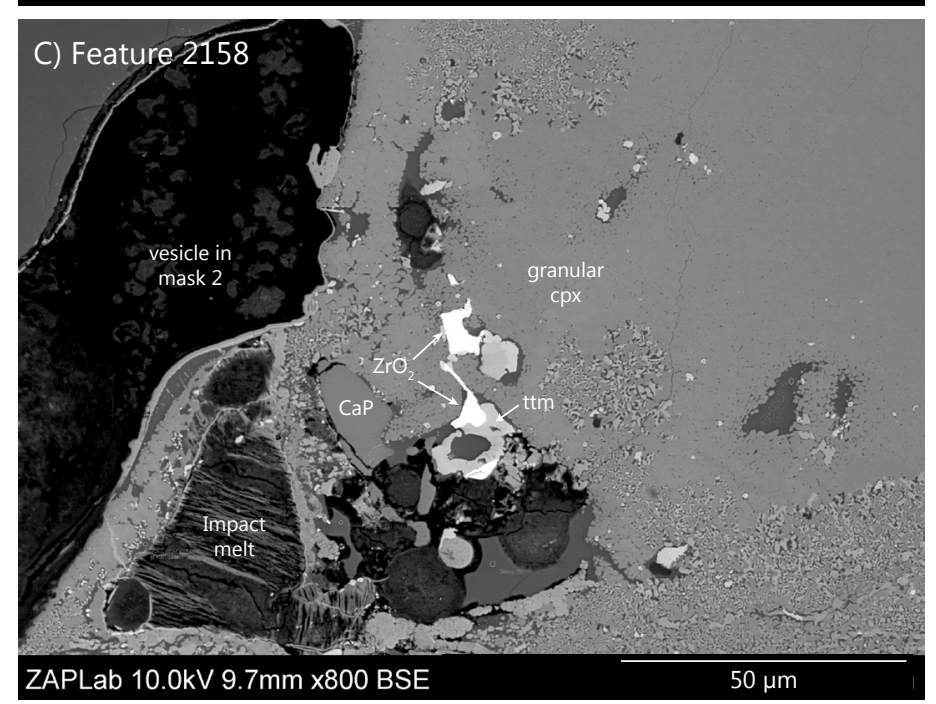

ZAPLab $10.0 \mathrm{kV} 9.7 \mathrm{~mm} \times 800 \mathrm{BSE}$

$50 \mu \mathrm{m}$

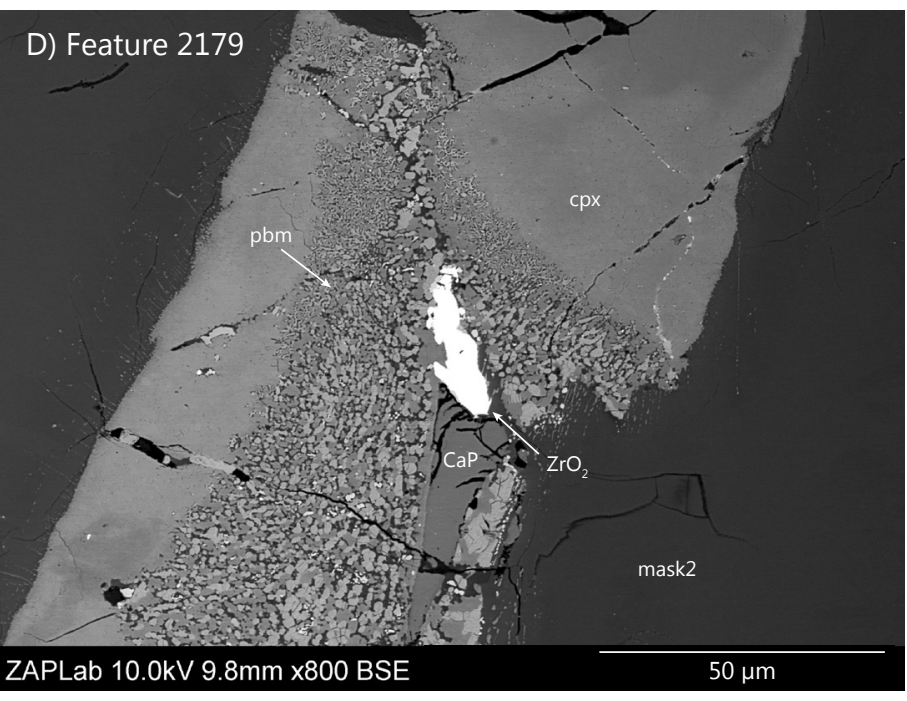

E) Feature 1983

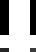

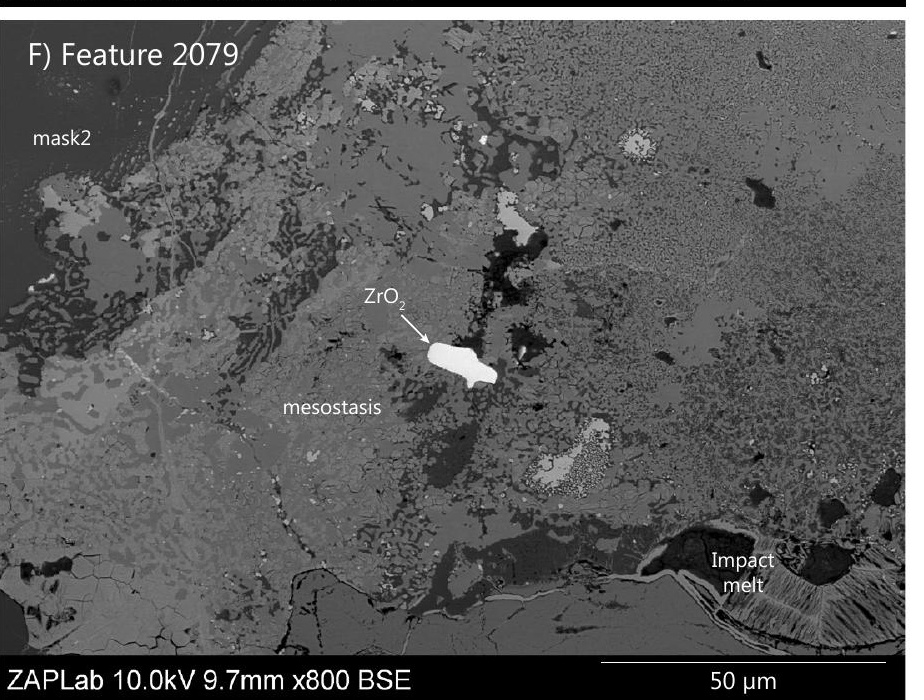


A) BSE

$$
\text { mask2 }
$$

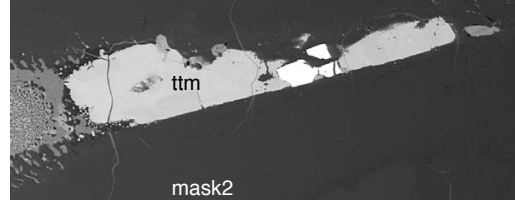

mask1

D) EBSD: Band Contrast
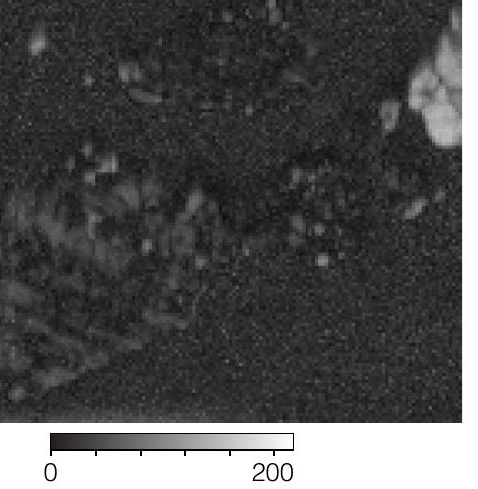

$50 \mu \mathrm{m}$
B) BSE

ZAPLab $10.0 \mathrm{kV} 9.7 \mathrm{~mm} \times 6.00 \mathrm{k}$ BSE

$5 \mu \mathrm{m}$

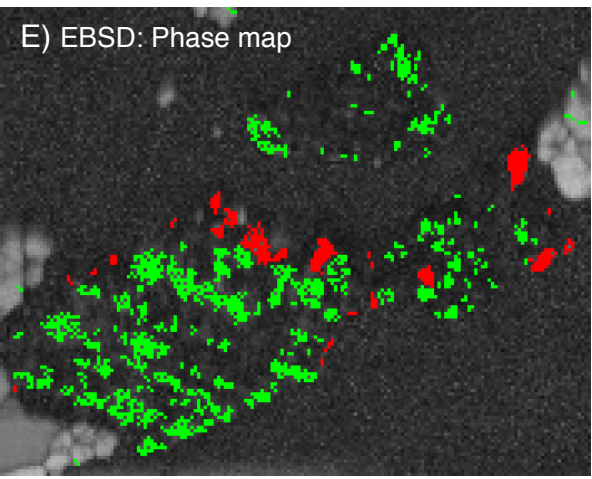

$\square$ Zircon 


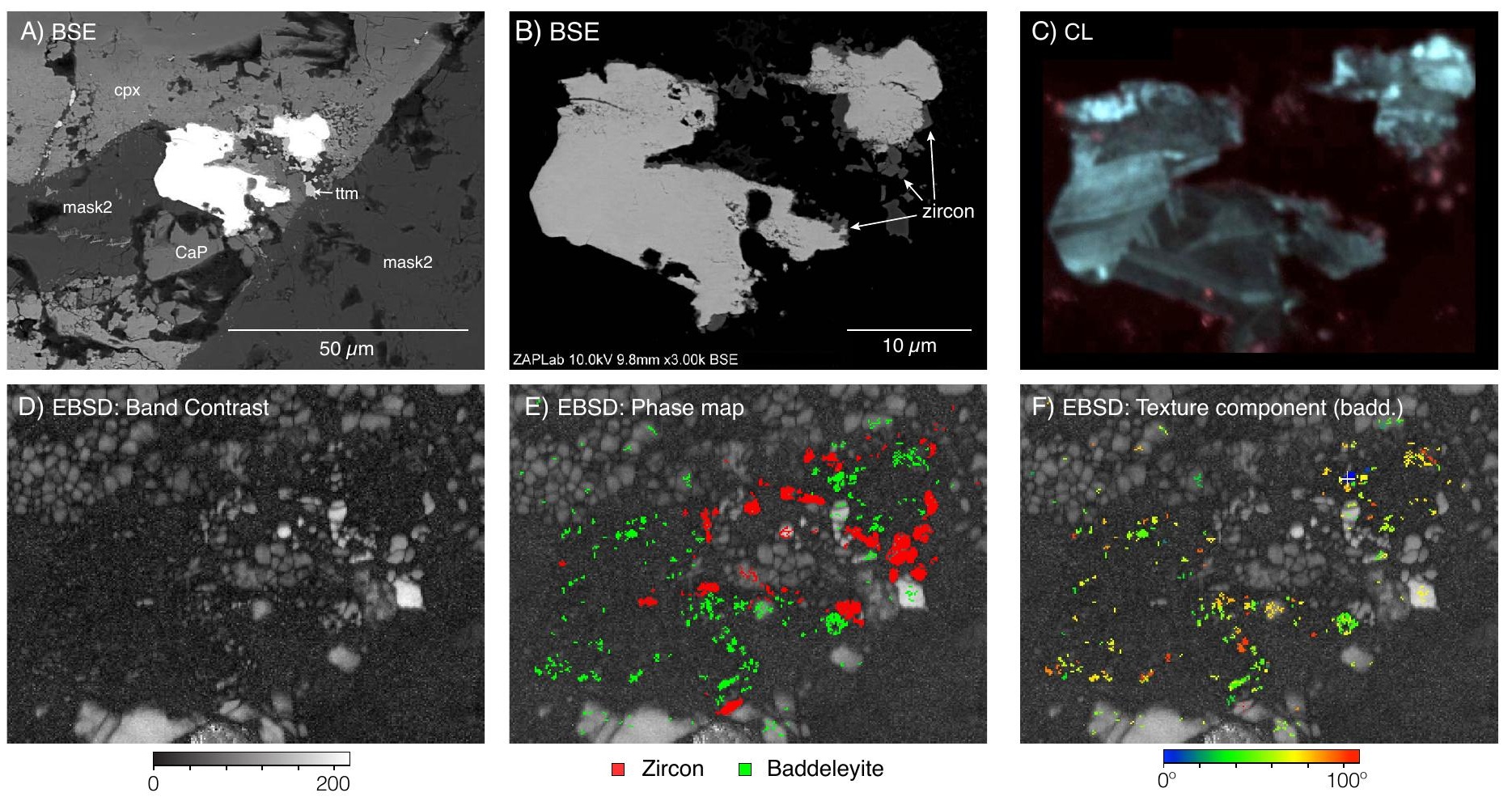


Original magmatic

baddeleyite

\section{Baddeleyite shock} Group 1

Crystalline, ubiquitous twinning on $\{100\}$ and $\{110\}$, both of which can be polysynthetic.

structure (EBSD/STEM

Feature ID

Baddeleyite shock

Group 2

\section{Smooth SE + BSE.}

Oscillatory or planar $\mathrm{CL}$

textures.

Crystalline, relict twinning.

Smooth SE + BSE.

Oscillatory or planar $\mathrm{CL}$

textures.

Highly degraded crystallinity, with nanocrystalline

structures. Quasi-amorphous

at EBSD interaction

lengthscales (tens $\mathrm{nm}$ ).

different twin domains)

1983, 2451, 2457, G15, 1539

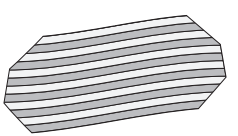

G16, 2158a, 378, 283, 1006, 3155, $\mathrm{G} 8,2179$

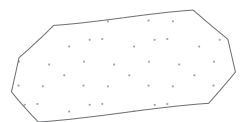

Zircon rim

Group 3 growth

Granular SE + BSE.

Patchy or cloudy CL.

Nano- to micro-crystalline.

Hundreds of $n m$ to $\mu \mathrm{m}$ scale granular crystallites with no discernable preferred orientation.

G1, G7, 1961, 2158b, 2, 303, 549, 1924, 2455, 2747, 3112.

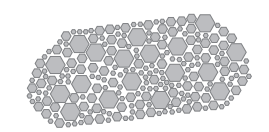

Thickest rims on G16, 1924, 2455, 378, 2454.

Smooth SE + BSE

$\mathrm{ZrO}_{2}$ grains from all Groups.

Crystalline zircon

\pm crystal-plastic deformation (up to $4^{\circ}$ misorientation)

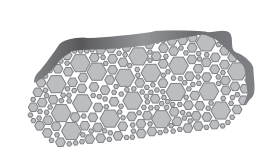

$<2 \mu \mathrm{m}$ thick zircon rims on 


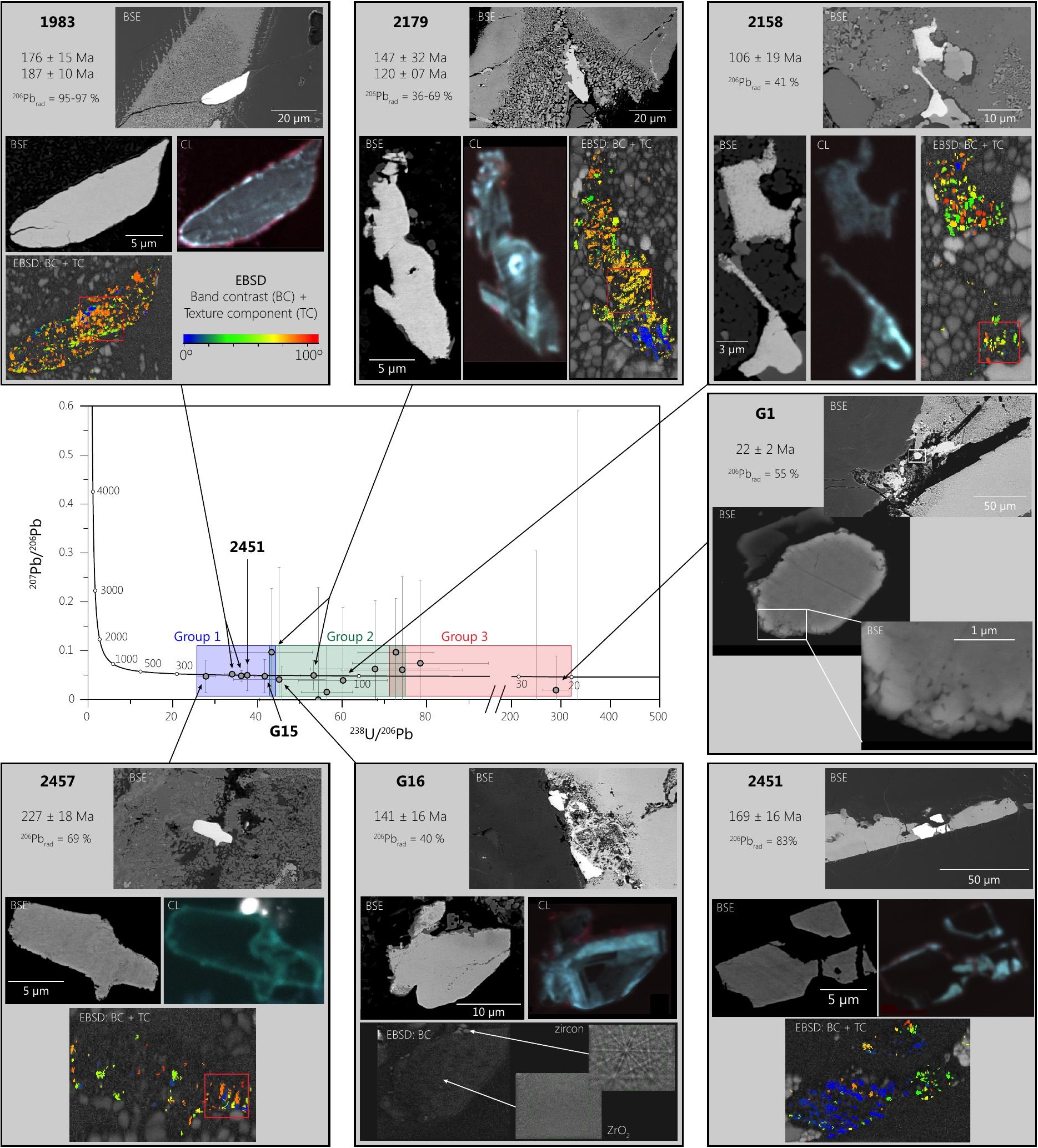


Instrumentation

SEM Model

EBSD system

EBSD software

\section{FEG-SEM settings}

Carbon coat $(<5 \mathrm{~nm})$

Acc. voltage $(\mathrm{kV})$

Working distance $(\mathrm{mm})$

Probe current (nA)

Tilt $\left({ }^{\circ}\right)$
Hitachi SU6600 FEG-SEM (Schottky electron source) Oxford Instruments Nordlys EBSD detector

HKL Channel 5
yes
20
19
8
70

EBSD data collection and processing EBSP collection time per frame (ms) 80

Background (frames)

64

EBSP noise reduction (frames) 7

EBSP noise reduction (binning) $4 \times 4$

EBSP noise reduction (gain) High

Hough resolution 60

Band detection min/max $\quad 5 / 7$

Step size (um) 50 to 150

Baddeleyite match unit Kudoh et al., (1986), Phys. Chem. Min. 12, 233-237.

Zircon match unit $\quad$ American Mineralogist (1979) 64, 196-201

Noise reduction

'wildspike' only 